\title{
Glutathione disulfide sensitizes hepatocytes to TNFa-mediated cytotoxicity via IKK- $\beta$ S-glutathionylation: a potential mechanism underlying non-alcoholic fatty liver disease
}

\author{
Xiaobing Dou ${ }^{1,2}$, Songtao $\mathrm{Li}^{1,3}$, Linfeng $\mathrm{Hu}^{2}$, Lei Ding ${ }^{2}$, Yue Ma², Wang Ma ${ }^{2}$, Hui Chai ${ }^{2}$ and Zhenyuan Song ${ }^{1,2,4}$
}

\begin{abstract}
Oxidative stress and TNFa are critically involved in the initiation and progression of non-alcoholic fatty liver disease (NAFLD). In this study, we investigated the effects of dysregulated glutathione homeostasis, a principal feature of oxidative stress, on TNFa-induced hepatotoxicity and its mechanistic implications in NAFLD progression. We showed that mice fed a high-fat diet (HFD) for 12 weeks developed hepatic steatosis and liver injuries, which were associated with not only TNFa overproduction but also hepatic glutathione dysregulation, characterized by GSH reduction and GSSG elevation. Moreover, consuming a HFD increased protein S-glutathionylation (protein-SSG formation) in the liver. Subsequent cell culture studies revealed that GSSG accumulation, as opposed to GSH reduction, sensitized hepatocytes to TNFa killing by reducing the TNFa-triggered NF-KB activity. GSSG prevented TNFa-induced activation of IKK- $\beta$, an upstream kinase in the NF-KB signaling pathway, by inducing IKK- $\beta$ glutathionylation (IKK- $\beta-$ SSG formation). In animal studies, in comparison to a control diet, HFD consumption resulted in increased hepatic IKK- $\beta$ SSG formation, leading to suppressed IKK- $\beta$ activation and subsequent NF-KB suppression. Furthermore, we found that HFD consumption also led to decreased hepatic expression of glutaredoxin, a key enzyme for de-glutathionylation. Similarly, $\mathrm{CdCl}_{2}$, a chemical inhibitor of glutaredoxin, sensitized hepatocytes to TNFa-mediated cytotoxicity. In conclusion, our data suggest that GSSG is a potent and clinically relevant sensitizer for TNFa-induced hepatotoxicity in NAFLD, which represents a potential therapeutic target for NAFLD.
\end{abstract}

\section{Introduction}

Non-alcoholic fatty liver disease (NAFLD) includes a spectrum of liver diseases ranging from simple steatosis (accumulation of triglyceride (TG) inside hepatocytes) to non-alcoholic steatohepatitis (NASH), which is defined as

Correspondence: Zhenyuan Song (song2008@uic.edu)

'Department of Kinesiology and Nutrition, University of Illinois at Chicago, Chicago, IL 60612, USA

${ }^{2}$ College of Life Science, Zhejiang Chinese Medical University, Hangzhou, Zhejiang 310053, P. R. China

Full list of author information is available at the end of the article

These authors contributed equally: Xiaobing Dou, Songtao Li. the presence of hepatic steatosis and inflammation along with hepatocyte death; many patients ultimately progress to fibrosis/cirrhosis and liver failure. The prevalence of NAFLD has increased rapidly over the last two decades, in parallel with the dramatic rise in obesity and diabetes. Because of its high prevalence in conjunction with obesity, diabetes, and insulin resistance, NAFLD has been increasingly appreciated as a hepatic manifestation of metabolic syndrome and is the leading cause of death from liver disease in the United States ${ }^{1-3}$. Although the overall disease progression of NAFLD has been

\section{(c) The Author(s) 2018}

\footnotetext{
Open Access This article is licensed under a Creative Commons Attribution-NonCommercial-NoDerivatives 4.0 International License, which permits any non-commercial CC. Creative Commons license. You do not have permission under this license to share adapted material derived from this article or parts of it. The images or other third party material in this article are included in the article's Creative Commons license, unless indicated otherwise in a credit line to the material. If material is not included in the article's Creative Commons license and your intended use is not permitted by statutory regulation or exceeds the permitted use, you will need to obtain permission directly from the copyright holder. To view a copy of this license, visit http://creativecommons.org/licenses/by-nc-nd/4.0/.
} 
characterized, the exact mechanism(s) underlying its initiation and progression remain poorly defined; there are no Food and Drug Administration-approved therapies available for the treatment of this disease.

Although much progress has been made over the last two decades, the precise cellular/molecular mechanism(s) underlying NAFLD development and progression have not been clearly defined. Hepatic steatosis results from an imbalance between TG synthesis and disposal. Both "hepatic" and "non-hepatic" mechanisms contribute to the development of hepatic steatosis. Insulin resistance in adipose tissue, which is often related to obesity, compromises the inhibitory effects of insulin on adipose tissue lipolysis, leading to increased free fatty acids (FFAs) in portal circulation ${ }^{4-6}$. In the liver, although both increased FFA uptake and upregulated de novo lipogenesis contribute to the development of hepatic steatosis, accumulating evidence suggests that increased FFA uptake plays a predominant role in the development of fatty livers ${ }^{1}$. This hypothesis is further supported by clinical observations that more than $60 \%$ of accumulated fatty acids in the liver are derived from the circulation in NAFLD patients ${ }^{7,8}$. $\mathrm{NASH}$ is the progressive form of NAFLD, characterized by hepatocyte death and hepatic inflammation. Although the mechanism(s) underlying NASH progression remain to be fully elucidated, accumulating evidence suggests that both oxidative stress and the pro-inflammatory cytokine tumor necrosis factor- $\alpha$ (TNF $\alpha)$ are critical contributors in this process 5 .

Oxidative stress has been implicated in the pathogenesis of NAFLD. Oxidative stress occurs when there is an imbalance between excessive reactive oxygen species (ROS) production and/or diminished cellular antioxidant defenses. Increased levels of ROS and lipid peroxidation products and/or decreased levels of antioxidant enzymes, such as superoxide dismutase (SOD) and catalase, and antioxidant compounds, such as glutathione, have been reported in both NAFLD/NASH patients as well as a variety of animal models of NAFLD ${ }^{9-14}$. Correspondingly, the protective effects of antioxidant supplementation have been observed in experimental models of NAFLD ${ }^{15-18}$. Moreover, the positive effects of vitamin E supplementation in the treatment of NASH have been documented in several clinical trials ${ }^{19,20}$.

Accumulated evidence suggests that increased TNF $\alpha$ production plays a central role in the pathogenesis of NAFLD, especially in its progression to NASH. Patients with NASH have increased TNFa levels in both the circulation and in hepatic tissues, which correlate with disease severity and mortality ${ }^{21}$. Moreover, a TNF $\alpha$ promoter polymorphism has been linked with susceptibility to NASH development ${ }^{22}$. Administration of an anti-TNFo antibody alleviates NASH and hepatic insulin resistance in $\mathrm{ob} / \mathrm{ob}$ mice $^{23}$. In addition, the protective effects of both a recombinant adiponectin injection in ob/ ob mice and metformin administration against NAFLD have been attributed, at least in part, to the inhibition of hepatic TNF $\alpha$ expression ${ }^{24,25}$. Importantly, TNF type 1 receptor knockout mice are resistant to the initiation and progression of NAFLD in response to both highcarbohydrate and methionine- and choline-deficient $\operatorname{diets}^{26,27}$.

TNF $\alpha$ induces both pro- and anti-apoptotic signaling pathways. Activation of nuclear factor- $\mathrm{kB}$ (NF- $\mathrm{kB}$ ) induces transcription of target genes that primarily encode survival proteins (e.g., cellular FLICE-like inhibitory protein and inhibitor of apoptosis proteins) via formation of the complex I signalosome after binding to TNF $\alpha$ receptor-1. Depending on the cellular signaling context, complex II can be formed from complex I, which activates caspase- 8 and pro-apoptotic pathways. Under physiological conditions, hepatocytes are resistant to TNFoinduced hepatotoxicity; pro-apoptotic pathways, including the activation of caspases and prolonged c-Jun $\mathrm{NH} 2$ terminal kinase (JNK) signaling, are antagonized by various NF- $\mathrm{kB}$ target genes ${ }^{28}$. How hepatocytes are sensitized to TNF $\alpha$-induced hepatotoxicity in the setting of NAFLD remains unknown.

Glutathione is a tripeptide that is synthesized from glutamate, cysteine, and glycine through two ATPconsuming reactions. It is the most abundant intracellular antioxidant and exists in both reduced (GSH) and oxidized (GSSG) forms. By donating a reducing equivalent to other unstable molecules, such as ROS, GSH is readily converted to GSSG, which can be converted back to GSH by the enzyme glutathione reductase $(\mathrm{GR})^{29}$. As a result, altered intracellular glutathione homeostasis has been widely used as an indicator of oxidative stress. Although both dysregulated hepatic glutathione homeostasis and TNF $\alpha$ overproduction are critically involved in the development of NAFLD, whether they can be synergistically implicated in hepatocyte death remains to be clearly defined. This study was performed to evaluate this hypothesis. Herein, we provide evidence that hepatic GSSG accumulation, which was observed in a high-fat diet (HFD)-fed model of NAFLD, rendered hepatocytes susceptible to TNFo-induced cell death. Mechanistic investigations revealed that the suppressed NF- $\mathrm{KB}$ activation due to increased ІкB kinase- $\beta$ (IKK- $\beta$ ) glutathionylation contributed to a GSSG-induced sensitization process.

\section{Materials and methods \\ Chemicals}

$\mathrm{H}_{2} \mathrm{O}_{2}$ was purchased from Fisher Scientific (Fair Lawn, $\mathrm{NJ})$. TNF $\alpha$ was purchased from PROSPEC (East Brunswick, NJ). Buthionine sulfoximine (BSO), 1, 3-bis (2chloroethyl)-1-nitrosourea (BCNU), diamide, and 
Hoechst 33342 were purchased from Sigma (St. Louis, $\mathrm{MO}$ ).

\section{Cell lines and culture conditions}

HepG2 cells, a human hepatoma cell line, were obtained from the American Type Culture Collection (Manassas, VA) and were cultured in Dulbecco's modified Eagle's medium (DMEM) containing $10 \%(\mathrm{v} / \mathrm{v})$ fetal bovine serum, $2 \mathrm{mM}$ glutamine, $5 \mathrm{U} / \mathrm{mL}$ penicillin, and $50 \mu \mathrm{g} / \mathrm{mL}$ streptomycin at $37^{\circ} \mathrm{C}$ in a humidified $\mathrm{O}_{2} / \mathrm{CO}_{2}$ (19:1) atmosphere. NCTC1469 cells, a normal mouse hepatocyte cell line, were obtained from the American Type Culture Collection and were cultured in DMEM containing 10\% $(\mathrm{v} / \mathrm{v})$ fetal horse serum, $2 \mathrm{mM}$ glutamine, $5 \mathrm{U} / \mathrm{mL}$ penicillin, and $50 \mu \mathrm{g} / \mathrm{mL}$ streptomycin at $37^{\circ} \mathrm{C}$ in a humidified $\mathrm{O}_{2} / \mathrm{CO}_{2}$ (19:1) atmosphere.

\section{Animal model and experimental protocol}

Male C57BL $/ 6$ mice (8 weeks old) weighing $25 \pm 0.5 \mathrm{~g}$ were obtained from the Jackson Laboratory (Bar Harbor, $\mathrm{ME}$ ). Mice were housed in the animal facilities at the University of Illinois at Chicago, Research Resources Center, and the studies were approved by the Institutional Animal Care and Use Committee, which is certified by the American Association of Accreditation of Laboratory Animal Care. During the week before the experiments

\section{Table 1 Composition of experimental diets}

\begin{tabular}{lll}
\hline Diet & Control (kcal\%) & High fat (kcal\%) \\
\hline Protein & 20 & 20 \\
Carbohydrate & 70 & 35 \\
Fat & 10 & 45 \\
Ingredient & $\mathbf{g}$ & $\mathbf{g}$ \\
Casein, 80 Mesh & 200 & 200 \\
L-Cystine & 3 & 3 \\
Corn starch & 315 & 72.8 \\
Maltodextrin 10 & 35 & 100 \\
Sucrose & 350 & 172.8 \\
Cellulose, BW200 & 50 & 50 \\
Soybean oil & 25 & 25 \\
Lard & 20 & 177.5 \\
Mineral Mix S10026 & 10 & 10 \\
Dicalcium phosphate & 13 & 13 \\
Calcium carbonate & 5.5 & 5.5 \\
Potassium citrate, 1 H2O & 16.5 & 16.5 \\
Vitamin Mix V10001 & 10 & 10 \\
Choline bitartrate & 2 & 2 \\
\hline
\end{tabular}

began, all mice were housed under conventional conditions and fed a standard diet and water ad libitum at the animal facility (Research Resource Facility). Thereafter, mice were divided into two groups $(n=6 /$ group $)$ and started on one of two treatments: a control diet (Con) and HFD. Both diets were obtained from Research Diets (New Brunswick, NJ). The detailed diet composition is shown in Table 1. All animals had access to food and water ad libitum. Mice were treated for 12 weeks before being sacrificed. At the end of the experiment, mice were anesthetized with Avertin $(300 \mathrm{mg} / \mathrm{kg}$ body weight $)$ after $4 \mathrm{~h}$ of fasting. Plasma, liver, and epididymal fat pad samples were harvested for analysis.

\section{Histological examination}

Upon sacrifice, a small piece of liver tissue from each animal was collected and fixed immediately in 10\% neutral buffered formalin. After paraffin embedding, the sections were stained with hematoxylin and eosin (H\&E). Histological assessment and scoring were performed by a pathologist blinded to the study conditions. The NAFLD activity scores (steatosis/inflammation/ballooning degeneration) were calculated using the clinical criteria outlined by Kleiner et al. ${ }^{30}$. Specifically, the amount of steatosis (percentage of hepatocytes containing fat droplets) was scored as $0(<5 \%), 1(5-33 \%), 2(>33-66 \%)$, and $3(>66 \%)$. Hepatocyte ballooning was classified as 0 (none), 1 (few), or 2 (many cells/prominent ballooning). Foci of lobular inflammation were scored as 0 (no foci), 1 ( $<2$ foci per $\times 200$ field), 2 (2-4 foci per $\times 200$ field), and 3 ( $>4$ foci per $\times 200$ field).

\section{Plasma TNFa assay}

Blood samples were drawn from the dorsal vena cava, and plasma was obtained by centrifuging the blood at $8000 \times g$ for $15 \mathrm{~min}$ at $4{ }^{\circ} \mathrm{C}$. Plasma TNF $\alpha$ concentration was colorimetrically measured using a commercially available enzyme-linked immunosorbent assay (ELISA) kit from R\&D Systems (Minneapolis, MN).

\section{Determination of hepatic TG Levels}

Hepatic TG accumulation was determined by both histochemical detection (Oil Red $\mathrm{O}$ staining) and biochemical assays. For Oil Red O Staining, liver tissues were frozen in Tissue-Tek CRYO-OCT (Fisher Scientific) and cryostat tissue sections were cut at $7 \mu \mathrm{m}$ thicknesses, fixed with $10 \%$ formalin for $10 \mathrm{~min}$, and stained following an Oil Red O procedure. For biochemical assays, total liver lipids were extracted using chloroform/methanol $(2: 1, \mathrm{v} /$ v). The protein levels in the homogenate were assayed using protein assay reagent (Bio-Rad, Hercules, CA) to normalize the amount of lipid extracted. TG levels were measured using assay kits from BioVision. 


\section{Lactate dehydrogenase assay}

Cell death was measured by the release of lactate dehydrogenase (LDH) into the culture medium. LDH activity was determined spectrophotometrically at $340 \mathrm{~nm}$ by following the rate of $\mathrm{NAD}^{+}$reduction in the presence of L-lactate. Cell death was shown by the change in cell viability, which was calculated as: (viable cell) $\%=($ optical density (OD) of untreated sample/OD of treated sample) $\times 100$.

\section{Hoechst staining}

Hoechst 33342 was used to specifically stain the nuclei of living and fixed cells and tissues, which allowed for the measurement of apoptosis within cells. Half an hour before the end of the incubation with the indicated stimulus, Hoechst was added to each well of 24-well plates at a final concentration of $1 \mu \mathrm{M}$. At the completion of the incubation, the cells were washed three times with ice-cold phosphatebuffered saline (PBS), and then, the fluorescence was measured by fluorescence microscopy at an emission wavelength of $460 \mathrm{~nm}$ using an excitation wavelength of $360 \mathrm{~nm}$ for the DCF fluorophore. All data are representative of at least three independent experiments.

\section{Caspase-3 activity assay}

Both hepatocytes and liver tissues were lysed on ice with lysis buffer containing protease inhibitors, and the proteins were collected. Caspase- 3 activities were measured with commercial kits according to the manufacturer's recommendations (Abcam, AB39401).

\section{ELISA assay for DNA fragmentation}

DNA fragmentation was quantified using a commercially available ELISA kit from Roche (Indianapolis, IN) in accordance with the manufacturer's instructions.

\section{Intracellular GSH/GSSG measurement}

The GSH and GSSG levels in whole liver tissues or cultured cells were measured using OxiSelect Total Glutathione (GSSG/GSH) Assay Kits in accordance with the manufacturer's instructions (Cell Biolabs, San Diego, CA, USA). The data were expressed as nanomoles per milligram of protein. All data are representative of at least three independent experiments.

\section{NF-KB (p65) DNA-binding activity analysis}

NF- $\mathrm{KB}$ (p65) DNA-binding activity in the nuclei of homogenized liver tissues or cultured cells was measured using ELISA kits (Cayman, MI, USA) in accordance with the manufacturer's instructions. In this method, a special double-stranded DNA sequence containing the NF- $\mathrm{KB}$ response element was immobilized onto the bottom of the wells of a 96-well plate.

\section{Real-time PCR}

Total RNA, from either frozen liver tissues or cultured cells, was isolated by phenol-chloroform extraction. For each sample, $1 \mu \mathrm{g}$ of total RNA was reverse-transcribed using a high-capacity cDNA reverse transcription kit (Applied Biosystems, Foster City, CA). cDNA was amplified in MicroAmp Optical 96-well reaction plates with SYBR Green PCR Master Mix (Applied Biosystems) on an Applied Biosystems Prism 7000 sequence detection system. Relative gene expression was calculated after normalization to a house-keeping gene (mouse or human $18 \mathrm{~S}$ rRNA). All of the primers for real-time PCR were purchased from QIAGEN (Germantown, MD) with the following catalog numbers: PPH00340B for C-IAP; PPH00333B for C-FLIP; and PPH01716B for MnSOD.

\section{Western blotting analysis}

Hepatocytes were lysed in RIPA buffer, and the isolated proteins were separated by SDS-polyacrylamide gel electrophoresis (SDS-PAGE) and transferred to $0.45 \mu \mathrm{m}$ polyvinylidene difluoride membranes. After transfer, membranes were blocked in $1 \%$ bovine serum albumin in PBS with $0.1 \%$ Tween-20 and probed with anti-PARP (NB100-56599, Novus Biologicals, Littleton, CO), antiGlutathione (AB19534, Abcam, Cambridge, MA), antiphospho-ІкB- $\alpha$ (9246), anti-ІкB- $\alpha$ (9242), anti-phosphoIKK- $\beta$ (2594), anti-IKK- $\beta$ (2370), or anti-p65 (8242) (Cell Signaling Technology, Danvers, MA) antibodies. Horseradish peroxidase-conjugated secondary antibodies and an enhanced chemiluminescence substrate kit were used for the detection of specific proteins.

\section{Immunoprecipitation}

Hepatocytes were lysed in an immunoprecipitation (IP) buffer $(150 \mathrm{mM} \mathrm{NaCl}), 50 \mathrm{mM}$ Tris- $\mathrm{HCl}, 1 \%$ Nonidet P$40, \mathrm{pH} 7.8$, and a mammalian cell-specific protease inhibitor cocktail. Total cellular extracts $(200 \mu \mathrm{g}$ of protein) were incubated with an anti-IKK- $\beta$ antibody $(1 \mu \mathrm{g} / \mathrm{mL})$ in IP buffer overnight at $4{ }^{\circ} \mathrm{C}$ on a rocker. The antibodyprotein mixture was agitated at 1500 r.p.m. with Protein A/G agarose beads (Santa Cruz Biotechnology) for $1 \mathrm{~h}$ at $4{ }^{\circ} \mathrm{C}$. The immunoprecipitates were washed four times with IP buffer. The washed immunoprecipitates were incubated in $50 \mu \mathrm{L}$ of $1 \times$ electrophoresis loading buffer and heated to $100^{\circ} \mathrm{C}$ for $5 \mathrm{~min}$. The beads were removed by centrifugation, and the supernatant was resolved by SDS-PAGE. The modification of IKK- $\beta$ by glutathione was analyzed by western blot.

\section{Gene silencing by small interfering RNA}

Transient gene silencing was attained by transfection of small interfering RNA (siRNA) into cells using siPORT lipid transfection reagent according to the manufacturer's instructions. Scrambled siRNA was used as a control. 
Gene silencing was verified by detecting proteins via immunoblotting analysis after transient transfection with siRNA.

\section{Statistical analysis}

All data are expressed as the mean \pm SD. Statistical analysis was performed using a one-way analysis of variance and was analyzed further by the Newman-Keuls test for significant differences. Differences between treatments were considered to be statistically significant at $p<0.05$.

\section{Results}

\section{NAFLD development was associated with TNFa} overproduction and perturbation of glutathione homeostasis in the liver

Long-term HFD consumption in mice represents a wellestablished animal model of NAFLD. As expected, a 12week course of HFD feeding induced early-stage liver pathologies of NAFLD in mice including fatty liver and liver injury, which were manifested by increased hepatic TG levels (Fig. 1a) and plasma alanine aminotransferase (ALT) levels (Fig. 1b), respectively. Massive hepatic TG accumulation and mild inflammation were also observed by H\&E staining (Fig. 1c). These hepatic pathological alterations were associated with significantly elevated plasma IL-6 concentrations and TNF $\alpha$ levels in both plasma and liver tissues (Fig. 1d, e). In comparison to control animals, HFD-fed mice demonstrated significantly lower GSH levels in the liver, whereas GSSG levels were significantly elevated (Fig. 1f), leading to a marked increase in the GSSG/GSH ratio (Fig. 1g) that was suggestive of perturbed hepatic glutathione homeostasis. In accordance with the elevated hepatic GSSG/GSH ratio in HFD-fed mice, HFD consumption markedly increased hepatic 4-hydroxynonenal formation (Fig. 1h), suggestive of lipid peroxidation in the liver.

\section{Perturbation of glutathione homeostasis sensitized hepatocytes to TNFa-induced cell death}

TNF $\alpha$ plays an important role in the progression of NAFLD; however, the exact mechanism(s) underlying TNF $\alpha$ hepatotoxicity in NAFLD remain to be clearly defined. The observations from our animal studies prompted us to examine whether dysregulated cellular glutathione homeostasis could render hepatocytes susceptible to TNF $\alpha$-induced cell death. The perturbation of cellular glutathione homeostasis was achieved by exposing hepatocytes to $\mathrm{H}_{2} \mathrm{O}_{2}$, which is a well-established method of inducing intracellular glutathione imbalance. As expected, $\mathrm{H}_{2} \mathrm{O}_{2}(0.2 \mathrm{mM})$ exposure disrupted cellular glutathione homeostasis in both HepG2 cells (a human hepatoma cell line) and NCTC1469 cells (a nontransformed mouse hepatocyte cell line), as demonstrated by an increase in the GSSG/GSH ratio over time (Fig. 2a, b), which was comparable to that observed in the livers of HFD-fed mice (Fig. 1f). To determine whether glutathione imbalances were capable of sensitizing hepatocytes to TNFa-induced cell death, hepatocytes were pretreated with $\mathrm{H}_{2} \mathrm{O}_{2}(0.1$ and $0.2 \mathrm{mM})$ for $2 \mathrm{~h}$, followed by TNFo addition $(40 \mathrm{ng} / \mathrm{mL})$. Cell death was assessed after $16 \mathrm{~h}$ by LDH release assay. Although TNF $\alpha$ at this dose exerted no cytotoxic effects, $\mathrm{H}_{2} \mathrm{O}_{2}$ pretreatment resulted in marked cell death in both HepG2 cells and NCTC1469 cells in response to TNF $\alpha$ challenge (Fig. 2c, d). These observations were further confirmed by Hoechst 33342 staining, which revealed extensive detachment of cells from the cell culture substratum and increases in apoptotic bodies of HepG2 cells incubated with $\mathrm{H}_{2} \mathrm{O}_{2}$ and TNFa for $16 \mathrm{~h}$ (Fig. 2e). Further analysis via western blot and DNA fragmentation ELISA analysis showed that TNFa addition increased PARP cleavage (a marker of apoptosis; Fig. 2f) as well as DNA fragmentation in HepG2 cells pretreated with exogenous $\mathrm{H}_{2} \mathrm{O}_{2}$ (Fig. 2g), which was associated with increased caspase-3 activation (Fig. 2h).

\section{Cellular GSSG accumulation, as opposed to GSH reduction, rendered hepatocytes susceptible to TNFa cytotoxicity}

Increased GSSG/GSG ratios in response to $\mathrm{H}_{2} \mathrm{O}_{2}$ exposure can stem from both GSH reduction and GSSG accumulation (data not shown). To differentiate between the potential involvement of these two consequences in $\mathrm{H}_{2} \mathrm{O}_{2}$-induced sensitization to TNF $\alpha$ hepatotoxicity, we first exposed HepG2 cells to (BSO), a potent inhibitor of gamma-glutamylcysteine synthetase, the rate-limiting enzyme in the glutathione synthesis pathway (Fig. 3a). As expected, $\mathrm{BSO}$ administration dramatically decreased intracellular GSH levels; however, unlike $\mathrm{H}_{2} \mathrm{O}_{2}$ exposure, BSO had no significant effect on GSSG levels (Fig. 3b). Similarly, in contrast to $\mathrm{H}_{2} \mathrm{O}_{2}$ exposure, BSO pretreatment did not increase cellular susceptibility to TNF $\alpha$ induced cell death (Fig. 3c). Next, we treated HepG2 cells with BCNU, a chemical inhibitor of GR, the enzyme converting GSSG back into GSH. BCNU treatment significantly increased cellular GSSG levels without affecting GSH levels (Fig. 3d, e). Interestingly, BCNU pretreatment sensitized hepatocytes to TNFo-induced cell death (Fig. 3f). To further confirm this observation, we transfected HepG2 cells with either scrambled siRNA or siRNA targeting GS overnight, followed by TNF $\alpha$ challenge. As shown in Fig. 3g, GS siRNA transfection, which led to more than $60 \%$ GS gene silencing, similarly increased the sensitivity of hepatocytes to TNF $\alpha$ killing, suggesting that increased GSSG accumulation mechanistically contributed to cellular glutathione imbalanceinduced susceptibility to TNFa-induced cell death. 


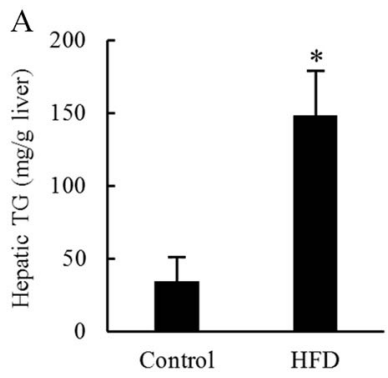

$\mathrm{C}$
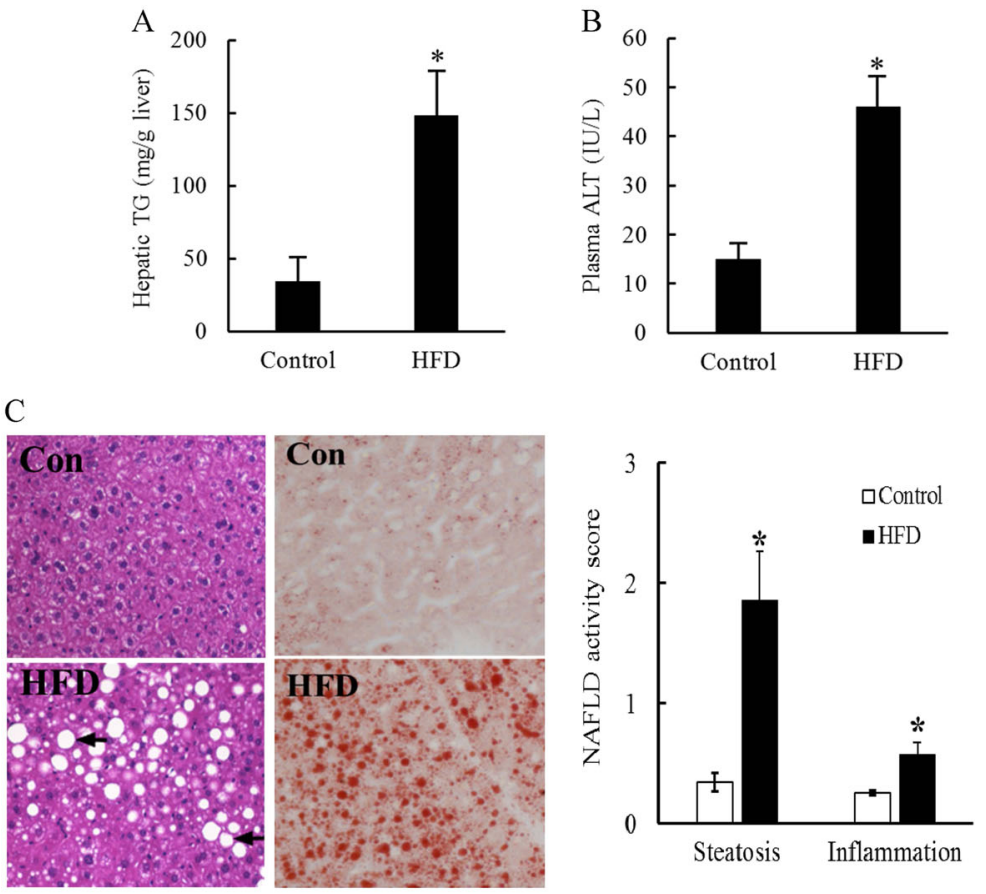

$\mathrm{D}$
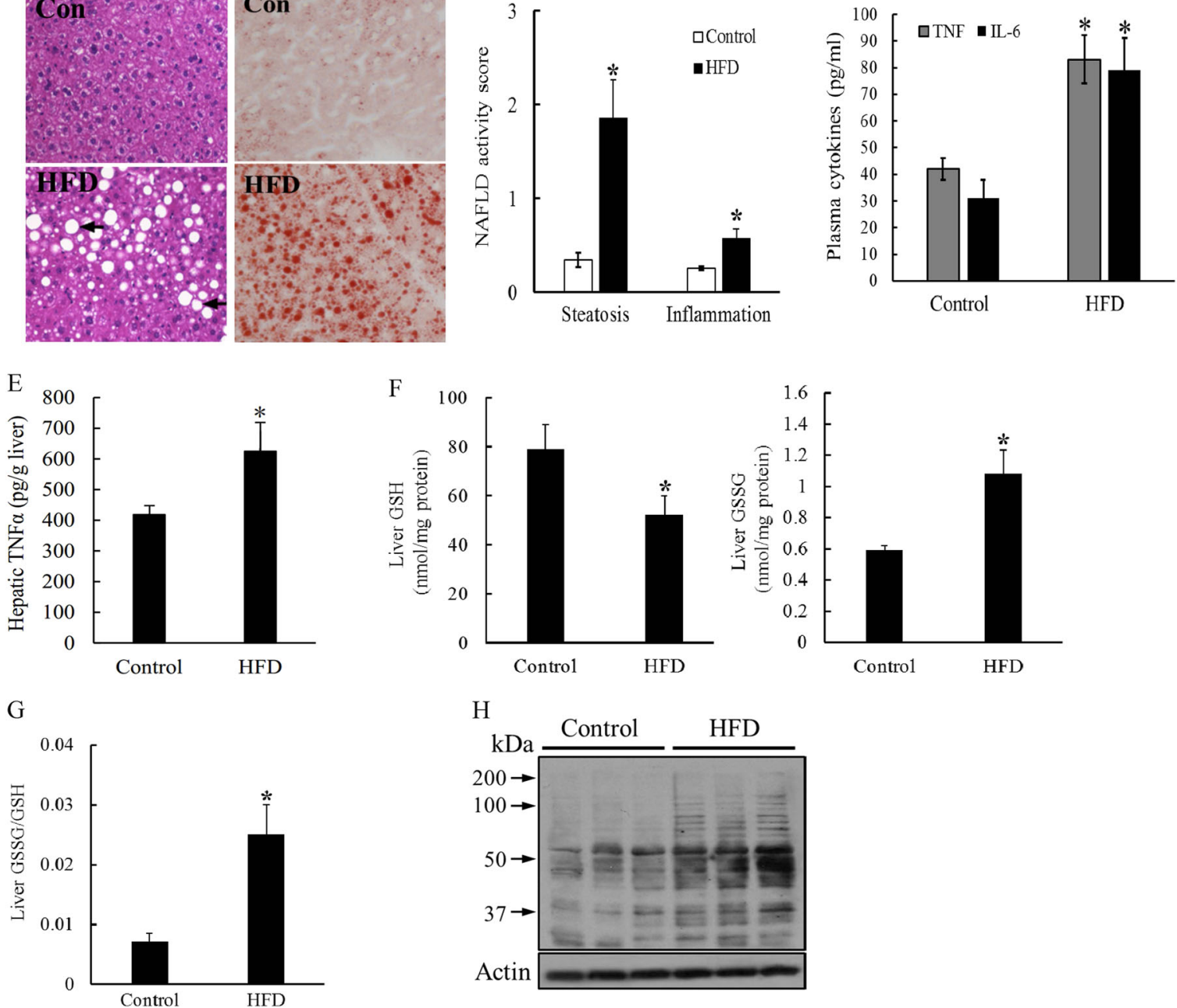

Fig. 1 NAFLD development is associated with increased TNFa production and dysregulated hepatic glutathione homeostasis. Male C57BL/ 6 mice were fed with control and high-fat diets (HFD) for 12 weeks. a Liver TG levels. b Plasma ALT levels. c Histological examination (H\&E and Oil Red O staining of liver tissue) and NAFLD histological activity scores. $\mathbf{d}$ Plasma TNFa and IL-6 levels. e TNFa levels in hepatic tissues. f GSH and GSSG levels in the liver. $\mathbf{g}$ Hepatic GSSG/GSH ratio. $\mathbf{h}$ Western blot analysis of long-term HFD feeding on hepatic. 4-HNE-protein adduct formation. Data are expressed as the mean $\pm \mathrm{SD}(n=6) .{ }^{*} p<0.05$ versus control

\section{GSSG accumulation induced cellular protein S-glutathionylation}

Post-translational protein $S$-glutathionylation occurs via the reversible addition of a proximal donor of glutathione to thiolate anions of cysteines in target proteins. GSSG is capable of causing protein $S$-glutathionylation or the reversible formation of protein-mixed disulfides (proteinSSG). As both $\mathrm{H}_{2} \mathrm{O}_{2}$ and $\mathrm{BCNU}$ exposure led to excessive 


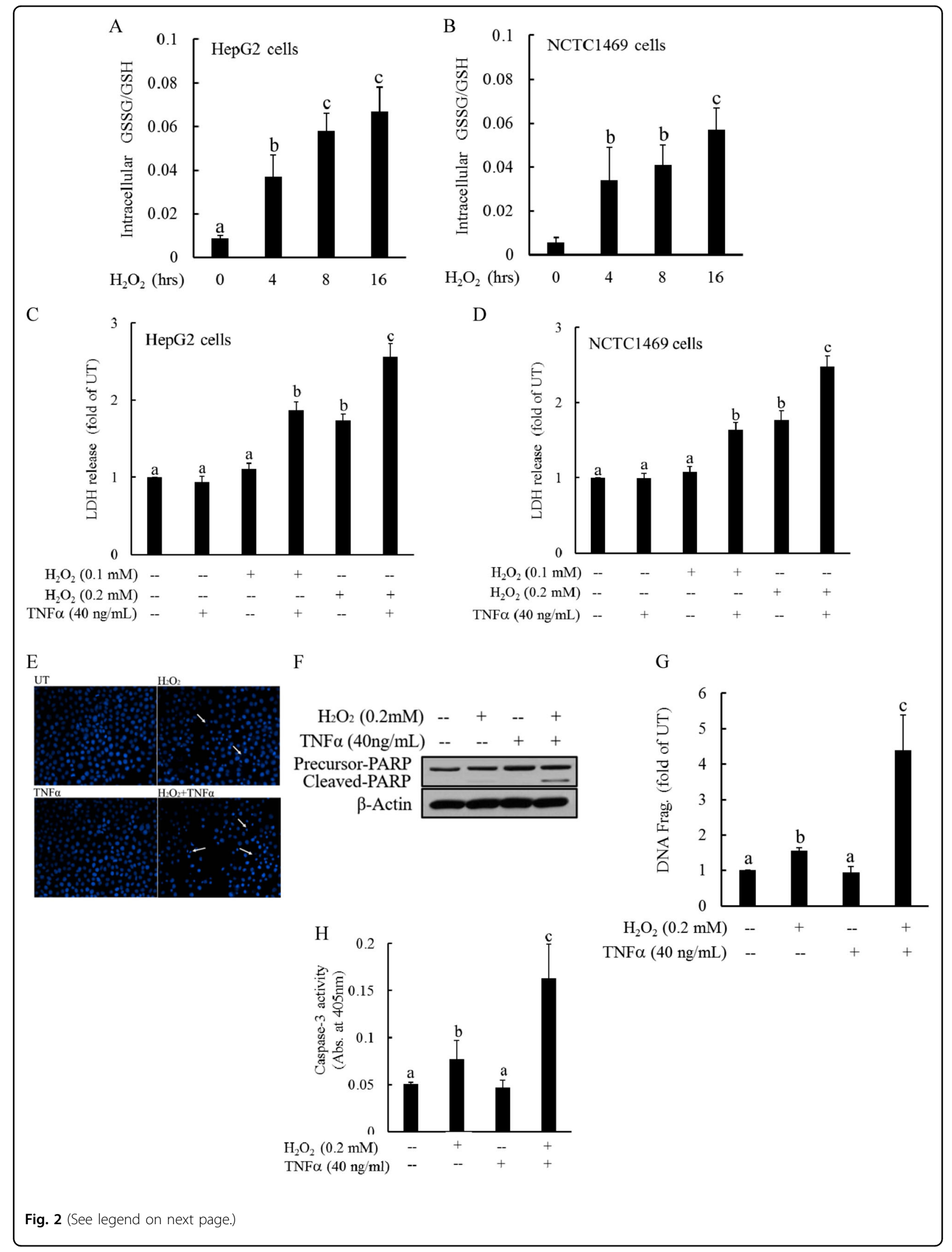


(see figure on previous page)

Fig. 2 Intracellular glutathione imbalance sensitizes hepatocytes to TNFa cytotoxicity. a, b Both HepG2 (a) and NCTC1469 cells (b) were exposed to complete DMEM containing $\mathrm{H}_{2} \mathrm{O}_{2}(0.2 \mathrm{mM})$ for the indicated time periods. Intracellular GSH and GSSG levels were measured, and the GSSG/GSH ratios were calculated. All values are denoted as the mean \pm SD from three or more independent studies. Bars with different characters differ significantly $(p<0.05)$. $\mathbf{c}, \mathbf{d} \mathrm{H}_{2} \mathrm{O}_{2}$ sensitizes hepatocytes to TNFa-induced cell death. HepG2 (c) and NCTC cells (d) were pretreated with $\mathrm{H}_{2} \mathrm{O}_{2}$ $(0.1$ and $0.2 \mathrm{mM})$ for $2 \mathrm{~h}$ before the addition of TNFa $(40 \mathrm{ng} / \mathrm{mL})$. Cell death was measured $16 \mathrm{~h}$ later by LDH release assay. Bars with different characters differ significantly $(p<0.05)$. e Hoechst 33342 staining. Arrows denote apoptotic bodies. $\mathbf{f}$ Western blot analysis of PARP cleavage. HepG2 cells were pretreated with $\mathrm{H}_{2} \mathrm{O}_{2}(0.2 \mathrm{mM})$ for $2 \mathrm{~h}$, followed by TNFa $(40 \mathrm{ng} / \mathrm{mL})$ stimulation. Whole-cell lysates were collected and subjected to western blot for the detection of PARP cleavage. $\mathbf{g}$ DNA fragmentation ELISA assay. $\mathbf{h}$ Caspase-3 activities. Bars with different characters differ significantly $(p<0.05)$

cellular GSSG accumulation, their impact on intracellular protein-GSSG adduct formation (protein $S$-glutathionylation) was subsequently examined in HepG2 cells by western blot analysis using a monoclonal GSSG antibody that specifically binds to GSSG-modified proteins. As shown in Fig. 4, the exposure of hepatocytes to both chemicals resulted in a significant increase in intracellular glutathionylated protein levels (Fig. 4a, b), which was not affected by the inclusion of TNF $\alpha$ in the media (Fig. 4c).

\section{Increased cellular protein S-glutathionylation sensitized hepatocytes to TNFa hepatotoxicity}

Increased cellular glutathionylated protein levels in response to GSSG accumulation prompted us to examine the effects of cellular protein $S$-glutathionylation on TNF $\alpha$-induced cell death. We pretreated HepG2 cells with diamide, a well-established protein $S$-glutathionylation induction agent, for $2 \mathrm{~h}$, followed by TNF $\alpha$ stimulation. As shown in Fig. 5a, diamide exposure markedly increased intracellular protein-GSSG adduct formation. Importantly, diamide pretreatment sensitized hepatocytes to TNF $\alpha$-induced cell death (Fig. 5b).

\section{GSSG sensitized hepatocytes to TNFa-mediated cytotoxicity via the induction of IKK- $\beta$ glutathionylation and subsequent NF-KB suppression}

NF- $\mathrm{kB}$ activation plays a critical role in protecting hepatocytes from $\mathrm{TNF} \alpha$-mediated cytotoxicity. Interference with the NF- $\mathrm{B}$ B signaling pathway sensitizes hepatocytes to TNF $\alpha$-induced death. After binding to its cell membrane receptor, TNF $\alpha$ activates NF- $\mathrm{KB}$ in the following sequence: (a) phosphorylation of the inhibitor of NF- $\kappa \mathrm{B}(\mathrm{I} \kappa \mathrm{B}-\alpha)$ by IKK; (b) ubiquitination and subsequent degradation of IкB- $\alpha$ by the $26 \mathrm{~S}$ proteasome; (c) nuclear translocation of predominantly p65/p50 dimers to induce transcription of target genes, including well-established FLICE-like inhibitory protein (c-FLIP) and apoptosis protein inhibitors (c-IAP). To determine whether GSSGinduced TNF $\alpha$ hepatotoxicity is associated with inhibition of the NF- $\mathrm{kB}$ signaling pathway, we first examined the effects of $\mathrm{H}_{2} \mathrm{O}_{2}, \mathrm{BCNU}$, and diamide treatment on TNF $\alpha$ stimulated NF- $\mathrm{kB}$ activation. As shown in Fig. 6a, TNF $\alpha$ supplementation in the media for $8 \mathrm{~h}$ induced robust gene expression levels of both c-FLIP and c-IAP, which were significantly downregulated by a 2 -h pretreatment with $\mathrm{H}_{2} \mathrm{O}_{2}, \mathrm{BCNU}$, or diamide. Moreover, $\mathrm{H}_{2} \mathrm{O}_{2}$ pretreatment suppressed TNF $\alpha$-induced nuclear p65/DNA-binding activity (Fig. 6b). IкB- $\alpha$ phosphorylation is an early-stage event in NF- $\mathrm{kB}$ activation and plays a central role in the determination of the subsequent steps involved in the nuclear translocation of $\mathrm{p} 65 / \mathrm{p} 50$. The phosphorylation status of IкB- $\alpha$ and total cytosolic IкB- $\alpha$ levels in HepG2 cells were determined by western blot analysis using cytosolic protein fractions. As shown in Fig. 6c, TNF $\alpha-$ stimulated increases in $\mathrm{I} \kappa \mathrm{B}-\alpha$ phosphorylation were almost completely eliminated by a 2 -h pretreatment with $\mathrm{H}_{2} \mathrm{O}_{2}$. As IKK- $\beta$ is the direct upstream kinase that phosphorylates IKB- $\alpha$, leading to its degradation, we next examined whether decreased TNF $\alpha$-induced IKB- $\alpha$ phosphorylation by $\mathrm{H}_{2} \mathrm{O}_{2}$ treatment was due to its effects on IKK- $\beta$ activity. As shown in Fig. $6 \mathrm{~d}, \mathrm{H}_{2} \mathrm{O}_{2}$ treatment reduced TNF $\alpha$-induced phosphorylation of IKK- $\beta$. Finally, we examined the effects of three GSSG-enhancing chemicals on IKK- $\beta$ glutathionylation (IKK- $\beta$-SSG adduct formation) by IP and immunoblotting. As shown in Fig. 6e, all three GSSG-enhancing chemicals increased the levels of IKK- $\beta$-SSG adducts, suggesting that GSSG accumulation restrained IKK- $\beta$ activity by promoting IKK- $\beta S$-glutathionylation, leading to subsequent NF-кB suppression.

\section{Long-term HFD consumption increased hepatic IKK- $\beta$ glutathionylation and NF-KB suppression}

The mechanistic investigations in our cell culture studies provided evidence suggesting that intracellular GSSG accumulation sensitizes hepatocytes to TNF $\alpha$ cytotoxicity via the induction of IKK- $\beta$ glutathionylation, leading to reduced IKK- $\beta$ phosphorylation and subsequent NF-kB suppression. To validate the in vivo relevance of our cell culture observations, we subsequently examined the effects of HFD on hepatic protein-SSG adduct formation, IKK- $\beta$ glutathionylation, and NF- $\kappa B$ activation. As shown in Fig. 7a, consistent with the increased hepatic GSSG accumulation in HFD-fed mice (Fig. 1f), long-term HFD consumption significantly increased hepatic protein $S$ glutathionylation when compared with a control diet, as 

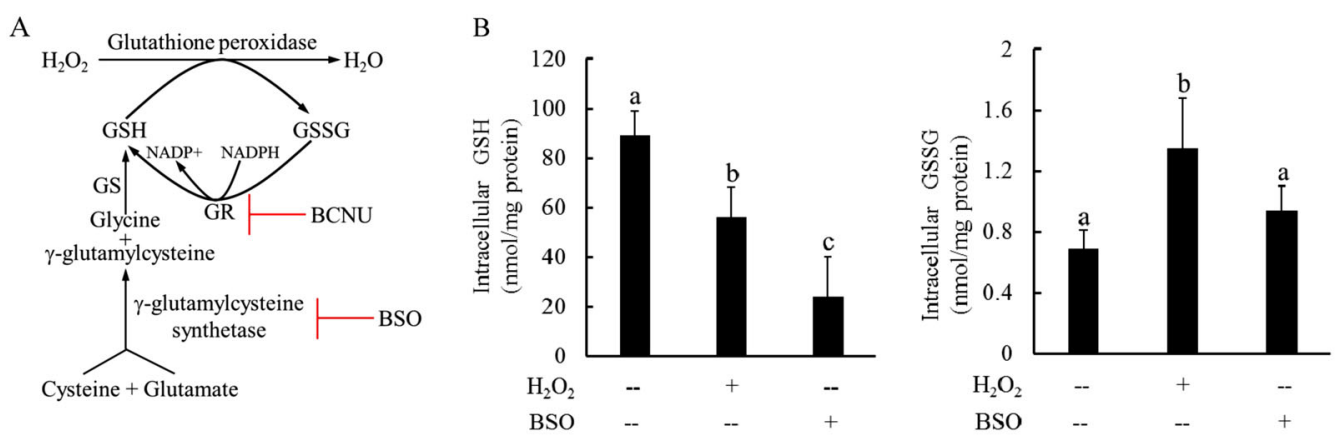

$\mathrm{C}$
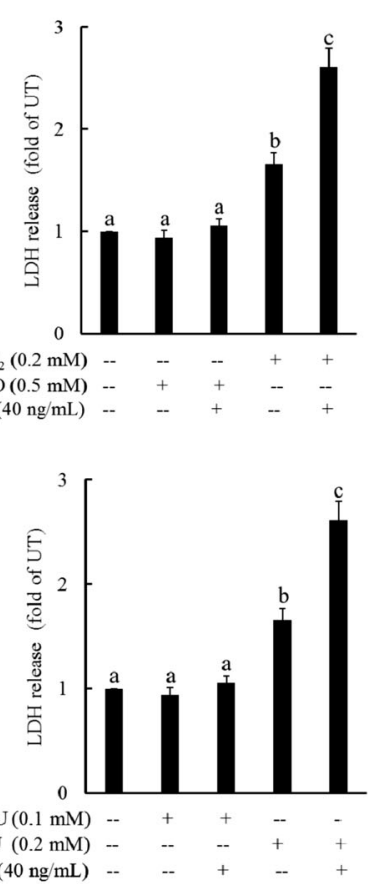

D

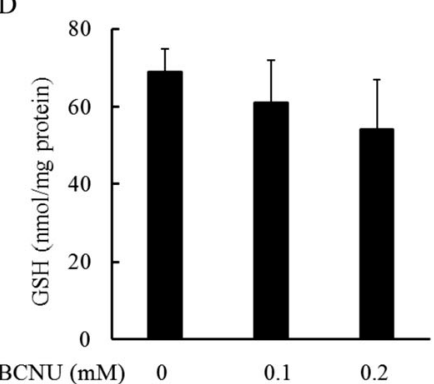

E

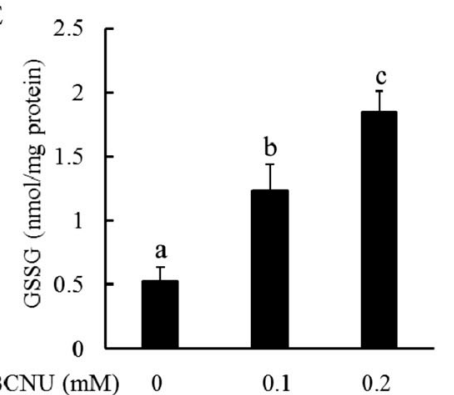

G

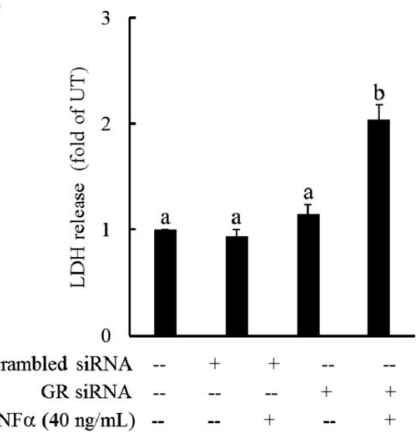

Fig. 3 Cellular GSSG accumulation renders hepatocytes susceptible to TNFa hepatotoxicity. a Schematic illustration of the glutathione synthesis pathway. HepG2 cells were pretreated with $\mathrm{BSO}(0.5 \mathrm{mM})$, a potent inhibitor of gamma-glutamylcysteine synthetase, for $2 \mathrm{~h} \mathrm{before} \mathrm{H}_{2} \mathrm{O}_{2}$ $(0.2 \mathrm{mM})$ addition. $\mathbf{b}$ Intracellular GSH and GSSG levels. All values are expressed as the mean \pm SD from three or more independent studies. Bars with different characters differ significantly $(p<0.05)$. c BSO pretreatment had no effect on TNFa-induced cell death. HepG2 cells were pretreated with either $\mathrm{BSO}(0.5 \mathrm{mM})$ or $\mathrm{H}_{2} \mathrm{O}_{2}(0.2 \mathrm{mM})$ for $2 \mathrm{~h}$ before TNFa $(40 \mathrm{ng} / \mathrm{mL})$ addition. Cell death was determined by the LDH release assay $16 \mathrm{~h}$ later. All values are expressed as the mean \pm SD from three or more independent studies. Bars with different characters differ significantly $(p<0.05)$. $\mathbf{d}$, e Inhibition of glutathione reductase (GR) significantly increased the intracellular GSSG levels without affecting GSH levels. HepG2 cells were treated with BCNU $(0.1 \mathrm{mM})$, a chemical inhibitor of GR, and the intracellular GSH and GSSG concentrations were measured at the indicated time points. All values are expressed as the mean \pm SD from three or more independent studies. Bars with different characters differ significantly $(p<0.05)$. $\mathbf{f}, \mathbf{g}$ GS inhibition sensitizes hepatocytes to TNFa-induced cell death. HepG2 cells were pretreated with BCNU (0.1 and $0.2 \mathrm{mM}$ ) for $2 \mathrm{~h}$ (f) or transfected with GS siRNA overnight $(\mathbf{g})$ before TNFa $(40 \mathrm{ng} / \mathrm{mL})$ addition. Cell death was measured by LDH assay $16 \mathrm{~h}$ later. All values are expressed as the mean \pm SD from three or more independent studies. Bars with different characters differ significantly $(p<0.05) .{ }^{*} p<0.05$ versus untreated cells

demonstrated by marked elevations in hepatic proteinSSG adducts by western blot analysis. Specifically, increased IKK- $\beta$-SSG formation and reduced IKK- $\beta$ phosphorylation was observed (Fig. 7b, c), consistent with the observations in our cell culture studies. Hepatic NF- $\kappa B$ activity was determined by measuring both NF- $\mathrm{BB}-$ DNA-binding activity using nuclear proteins and the expression of NF- $\mathrm{KB}$ target genes. In comparison to control diet, HFD consumption resulted in significant reductions in both NF-kB-DNA-binding activity (Fig. 7d) and expression of NF- $\mathrm{kB}$ target genes, including $c-F L P, c-$ $I A P$, and $M n S O D$ (Fig. 7e). As the activation of both JNK and caspase- 3 contributed to TNFo-induced cell death with NF-kB inhibition, we examined the effects of HFD 

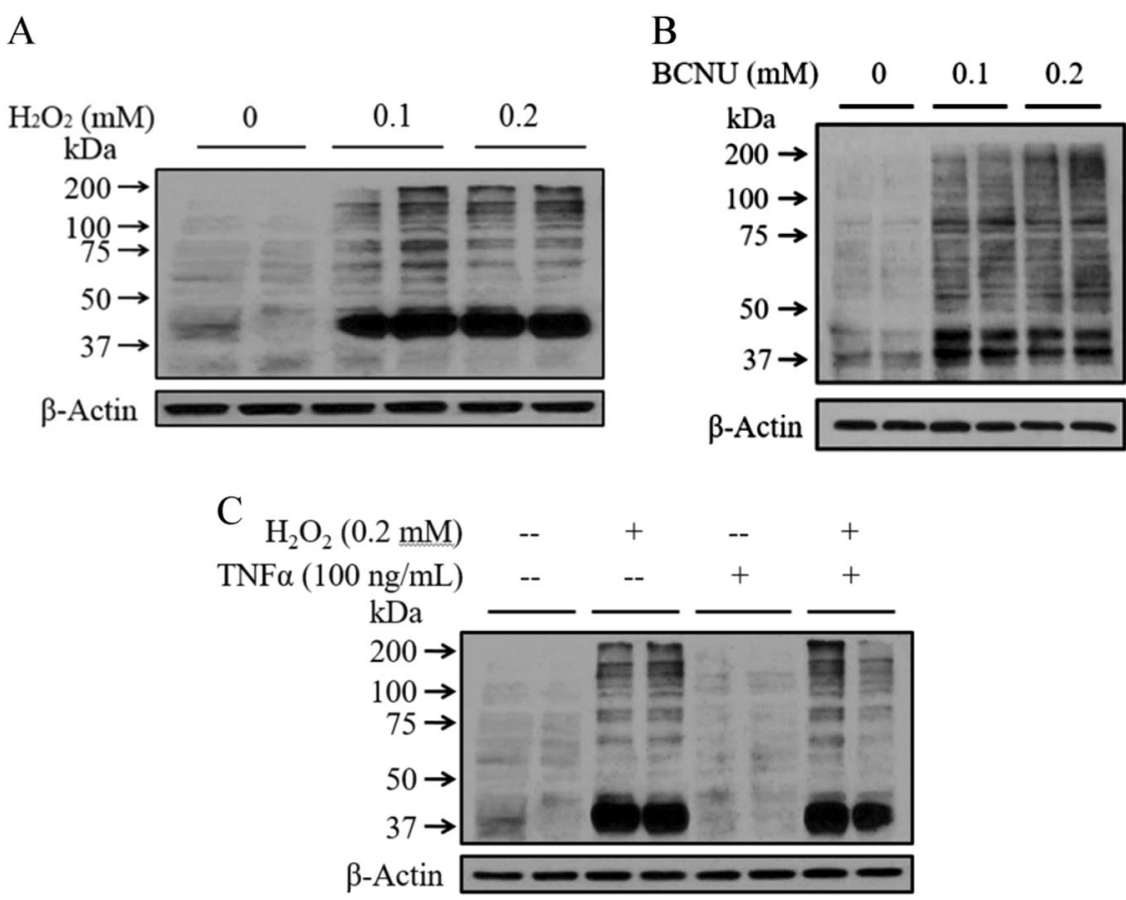

Fig. 4 GSSG accumulation induces cellular protein S-glutathionylation. a-c Exogenous $\mathrm{H}_{2} \mathrm{O}_{2}$ (a) and $\mathrm{BCNU}$ (b) treatment increased the intracellular glutathionylated protein levels. HepG2 cells were incubated with exogenous $\mathrm{H}_{2} \mathrm{O}_{2}(0.1$ and $0.2 \mathrm{mM})$ or $\mathrm{BCNU}(0.1$ and $0.2 \mathrm{mM})$ for $2 \mathrm{~h}$. Whole-cell lysates were collected and subjected to western blot for the detection of intracellular GSSG levels
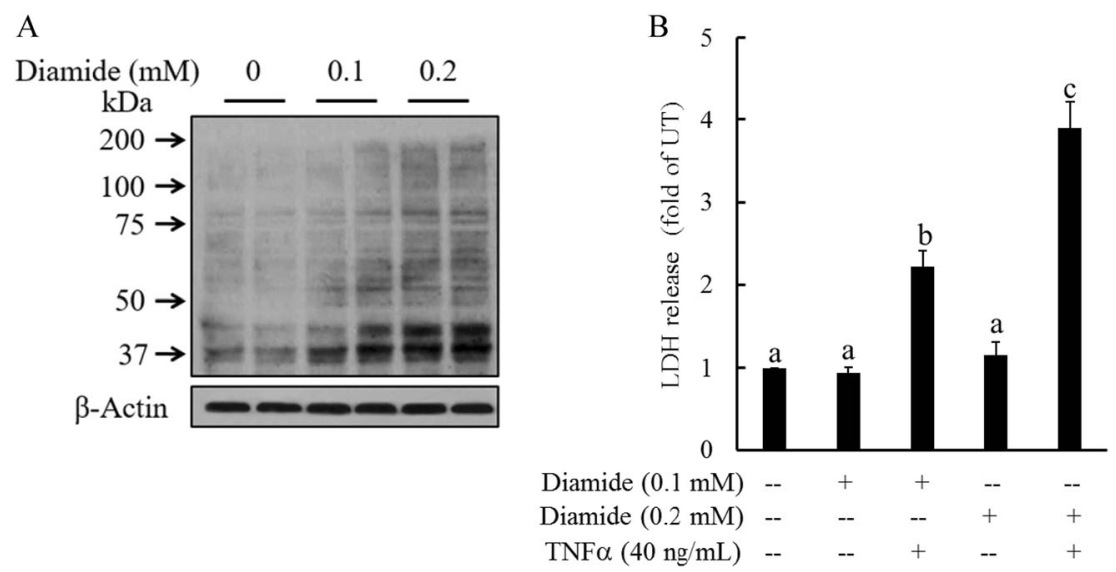

Fig. 5 Increased cellular protein S-glutathionylation sensitizes hepatocytes to TNFa hepatotoxicity. a Diamide, a protein S-glutathionylation induction agent, increased intracellular protein-GSSG adduct formation. HepG2 cells were incubated with exogenous diamide (0.1 and $0.2 \mathrm{mM})$ for 2 $\mathrm{h}$. Whole-cell lysates were collected and used for the detection of the intracellular GSSG levels by western blot analysis. $\mathbf{b}$ Diamide pretreatment sensitized hepatocytes to TNFa-induced cell death. HepG2 cells were pretreated with diamide ( 0.1 and $0.2 \mathrm{mM})$ for $2 \mathrm{~h}$ before TNFa ( $40 \mathrm{ng} / \mathrm{mL}$ ) addition. Cell death was measured by the LDH assay $16 \mathrm{~h}$ later. All values are expressed as the mean \pm SD from three or more independent studies. Bars with different characters differ significantly $(p<0.05)$

consumption on the hepatic activation status of JNK and caspase-3 cleavage. Our results clearly demonstrated that HFD consumption was associated with hepatic activation of both JNK and caspase-3 (Fig. 7f).

\section{Long-term HFD consumption reduced hepatic expression} of glutaredoxins

The de-glutathionylation of protein-mixed disulfides is primarily catalyzed by glutaredoxins $(\mathrm{Grxs})^{31}$. Therefore, in addition to GSSG accumulation, a decrease in Grx expression/activity may also lead to increased protein $S$ - 


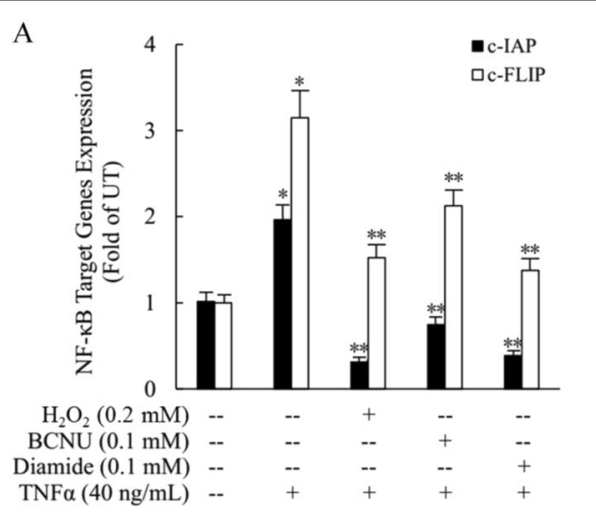

B

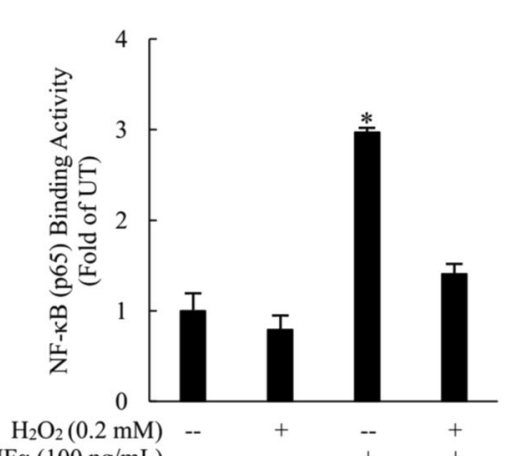

C

$\mathrm{H}_{2} \mathrm{O}_{2}(0.2 \mathrm{mM}) \quad-\quad+\quad-\quad+$

\begin{tabular}{|c|c|c|c|}
\hline $\mathrm{TNF} \alpha(100 \mathrm{ng} / \mathrm{mL})$ & - & + & + \\
\hline p-I $\kappa$ B- $\alpha$ & $\Gamma-$ & $=$ & 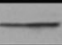 \\
\hline I $\kappa$ B- $\alpha$ & & & \\
\hline$\beta$-Actin & $-\infty$ & - & $=$ \\
\hline
\end{tabular}

D

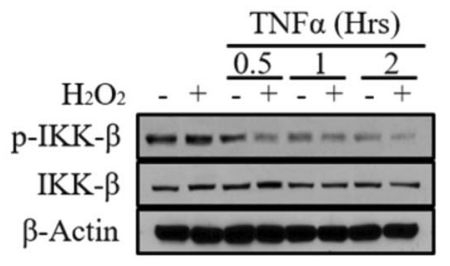

E

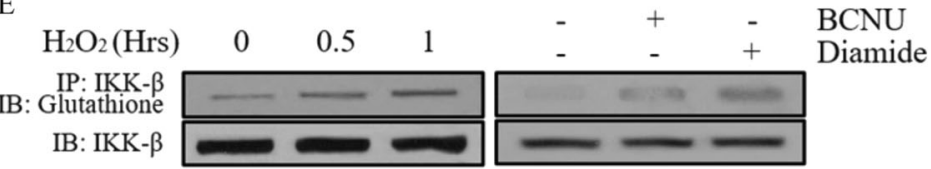

Fig. 6 GSSG suppresses TNFa-stimulated NF-KB transactivation via induction of IKK- $\beta$ glutathionylation. a $\mathrm{H}_{2} \mathrm{O}_{2}$, $\mathrm{BCNU}$, or diamide pretreatment suppressed NF-KB-mediated gene expression after TNFa stimulation. HepG2 cells were pretreated with $\mathrm{H}_{2} \mathrm{O}_{2}, \mathrm{BCNU}$ or diamide for $2 \mathrm{~h}$ before TNFa $(40 \mathrm{ng} / \mathrm{mL})$ addition. Total RNA was isolated, and NF-KB-targeted gene expression was determined by real-time RT-PCR. All values are expressed as the mean \pm SD from three or more independent studies. ${ }^{*} p<0.05$, ${ }^{* *} p<0.01$ versus TNFa-treated cells. $\mathbf{b} \mathrm{H}_{2} \mathrm{O}_{2}$ pretreatment suppresses TNFa-induced nuclear p65/DNA-binding activity. HepG2 cells were pretreated with $\mathrm{H}_{2} \mathrm{O}_{2}(0.2 \mathrm{mM})$ for $2 \mathrm{~h}$ before TNFa $(100 \mathrm{ng} / \mathrm{mL})$ addition. Four hours later, nuclear fractions were isolated and subjected to ELISA for the measurement of p65/DNA-binding activities. All values are expressed as the mean \pm SD from three or more independent studies. ${ }^{*} p<0.05$ versus TNFa-treated cells. $\mathbf{c} \mathrm{H}_{2} \mathrm{O}_{2}$ pretreatment abolished the TNFa-stimulated increase in IKB-a phosphorylation. HepG2 cells were pretreated with $\mathrm{H}_{2} \mathrm{O}_{2}(0.2 \mathrm{mM})$ for $2 \mathrm{~h}$ before TNFa $(100 \mathrm{ng} / \mathrm{mL})$ stimulation, and cell lysates were collected 15 min after TNFa exposure for western blot analysis of phosphorylated IKB-a. $\mathbf{d} \mathrm{H}_{2} \mathrm{O}_{2}$ pretreatment inhibited TNFa-stimulated IKK- $\beta$ activation/phosphorylation. HepG2 cells were pretreated with $\mathrm{H}_{2} \mathrm{O}_{2}$ for $2 \mathrm{~h}$ before TNFa $(100 \mathrm{ng} / \mathrm{mL})$ stimulation, and cell lysates were collected at the indicated time points for western blot analysis of the phosphorylated IKK- $\beta$ levels. e $\mathrm{H}_{2} \mathrm{O}_{2}, \mathrm{BCNU}$, or diamide pretreatment increased the IKK- $\beta$ SSG levels. HepG2 cells were treated with $\mathrm{H}_{2} \mathrm{O}_{2}, \mathrm{BCNU}$, or diamide for $1 \mathrm{~h}$, and cell lysates were collected and subjected to immunoprecipitation and western blot analysis for glutathionylated IKK- $\beta$. IB immunoblotting, IP immunoprecipitation

glutathionylation. Accordingly, we evaluated the effects of long-term HFD consumption on Grx expression by western blot. As shown in Fig. 8a, both Grx1 and Grx2 expression levels were reduced in livers from HFD-fed mice compared to control mice. Consistently, in HepG2 cells, $\mathrm{CdCl}_{2}$ (a chemical inhibitor of Grx) treatment led to increased protein-SSG formation (Fig. 8b) and sensitized cells to TNF $\alpha$-mediated hepatotoxicity (Fig. 8c).

\section{Discussion}

Hepatocyte death is one of the primary features of $\mathrm{NASH}$, the progressive form of NAFLD ${ }^{3}$. Both oxidative stress and TNF $\alpha$ have been critically implicated in the progression of NAFLD ${ }^{5}$. Using a long-term HFD-fed mouse model of NAFLD, we demonstrated in this study that NAFLD development occurs concomitantly with dysregulated hepatic glutathione homeostasis characterized by decreased GSH and increased GSSG, and 


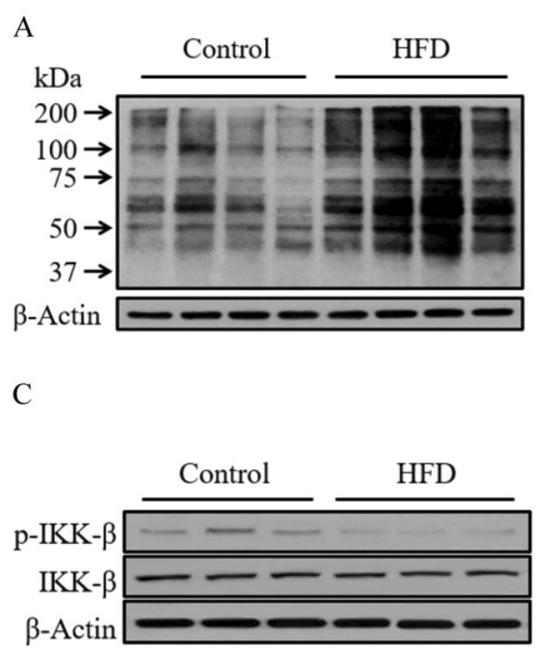

B

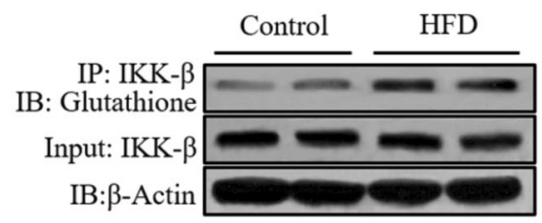

D

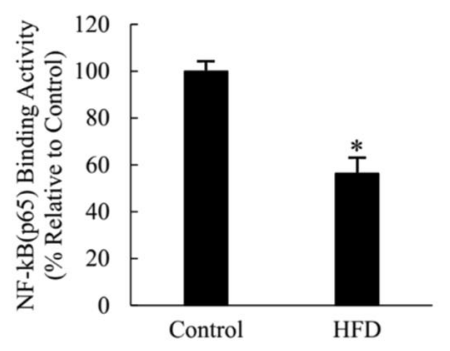

$\mathrm{E}$

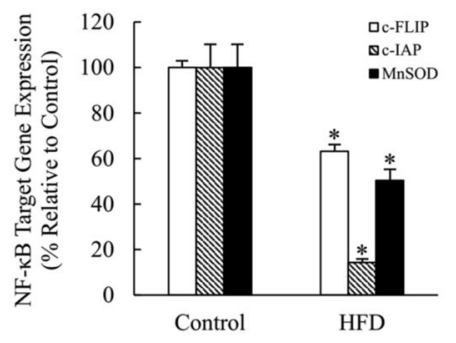

F
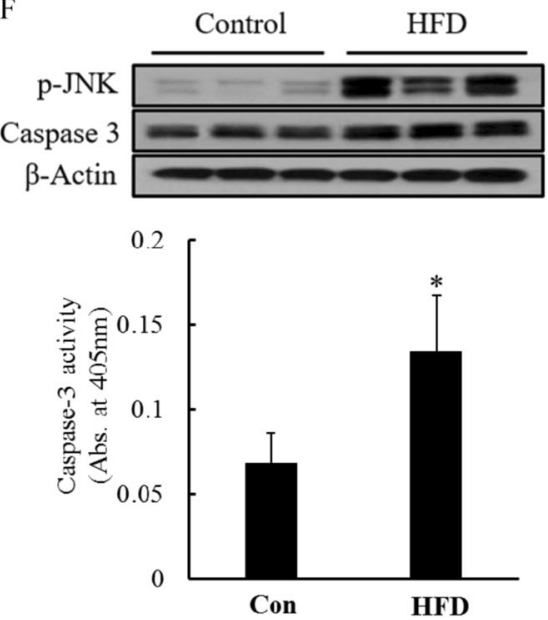

Fig. 7 Long-term HFD consumption increases IKK- $\beta$ glutathionylation and suppresses NF-KB activation in the liver. Male C57BL/6 mice were fed with either a control diet or high-fat diet (HFD) for 12 weeks. a Hepatic protein-SSG adduct levels. b Hepatic glutathionylated IKK- $\beta$ levels. $\mathbf{c}$ Hepatic IKK- $\beta$ phosphorylation. $\mathbf{d}$ Hepatic nuclear p65/DNA-binding activity. e NF-KB-targeted gene expression in the liver. Data are expressed as the mean \pm SD $(n=6) .{ }^{*} p<0.05$ versus control. $\mathbf{f}$ Hepatic JNK and caspase-3 activation

increased TNF $\alpha$ protein levels in both the circulation and the liver. To determine whether dysregulated hepatic glutathione homeostasis and TNF $\alpha$ can synergistically contribute to hepatocyte death, we performed cell culture studies using both human hepatoma cells and mouse non-transformed hepatocytes; these showed that increased cellular GSSG accumulation, rather than GSH reduction, rendered hepatocytes susceptible to TNF $\alpha$-induced cytotoxicity. Further mechanistic investigations determined that the elevation of intracellular GSSG levels resulted in NF- $\mathrm{KB}$ inhibition by facilitating glutathionylated IKK- $\beta$ (IKK- $\beta$-SSG) formation, leading to enhanced TNF $\alpha$ hepatotoxicity. Consistently, the livers of HFD-fed mice showed increased IKK- $\beta$-SSG levels, decreased IKK- $\beta$ phosphorylation, and suppressed NF- $\mathrm{KB}$ activation when compared to these from control animals. Finally, we demonstrated that longterm HDF consumption downregulated the expression of hepatic Grx, the enzyme catalyzing the deglutathionylation reaction ${ }^{32}$; Grx gene silencing in hepatocytes further sensitized hepatocytes to TNF $\alpha$ mediated killing.

Glutathione is one of the most abundant and potent intracellular antioxidants. Under conditions of oxidant attack, GSH is rapidly converted to GSSG, making the elevation of the intracellular GSSG/GSH ratio a widely accepted marker for oxidative stress. GSSG generated in these processes can be either recycled to GSH by a 


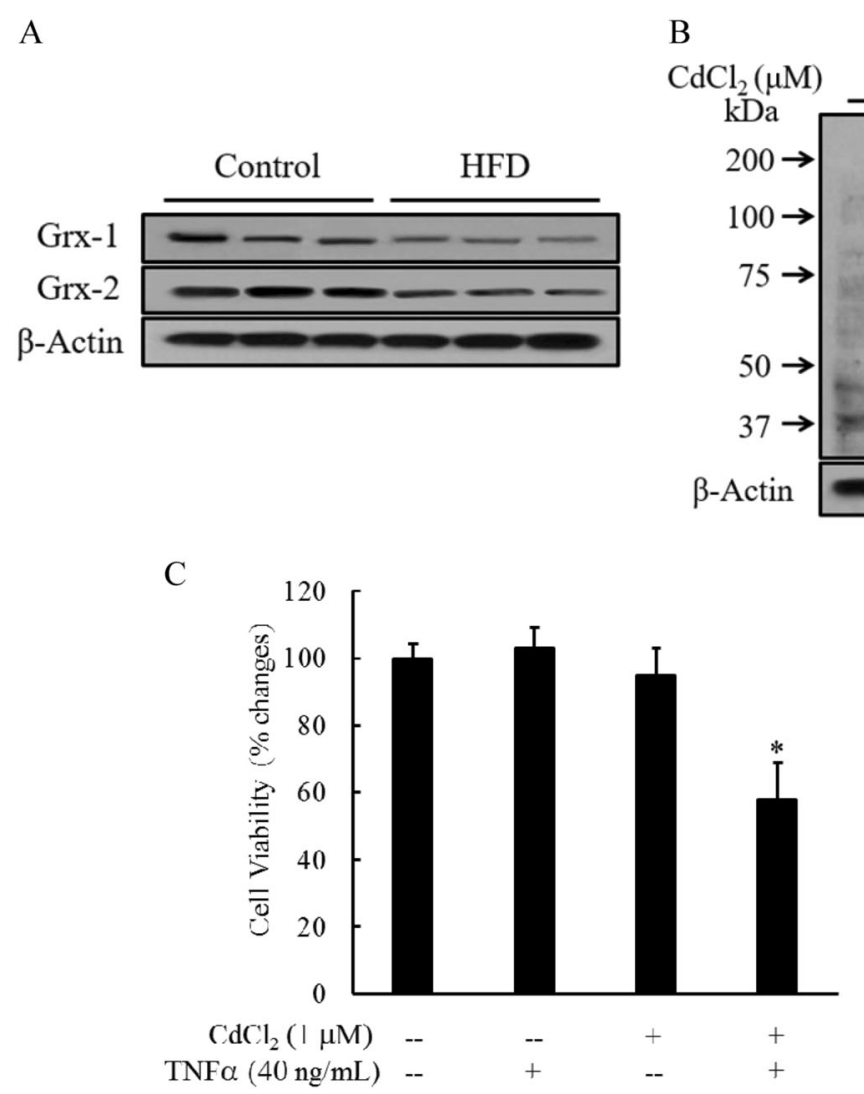

Fig. 8 Long-term HFD consumption reduces hepatic expression of glutaredoxins (Grxs). Male C57BL/6 mice were fed with either a control diet or high-fat diet (HFD) for 12 weeks. a Hepatic expression of Grx1 and Grx2. b Cdcl , a chemical inhibitor of Grx, increased protein-SSG formation in hepatocytes. HepG2 cells were incubated with $\mathrm{Cdcl}_{2}(1 \mu \mathrm{M})$ for $16 \mathrm{~h}$. Whole-cell lysates were collected and subjected to western blot analysis for the detection of the intracellular protein-SSG levels. $\mathbf{c} \mathrm{Cdcl}_{2}$ pretreatment sensitized hepatocytes to TNFa-induced cell death. HepG2 cells were pretreated with $\mathrm{CdCl}_{2}(1 \mu \mathrm{M})$ for $2 \mathrm{~h}$ before TNFa $(40 \mathrm{ng} / \mathrm{mL})$ addition. Cell death was measured by $\mathrm{LDH}$ assay $16 \mathrm{~h}$ later. All values are expressed as the mean \pm SD from three or more independent studies. ${ }^{*} p<0.01$ versus untreated cells

$\mathrm{NADPH}$-dependent reaction, catalyzed by $\mathrm{GR}^{3}$, or pumped out of the cell by ATP-dependent processes, with multidrug resistance-associated protein-1 (MRP-1) being the major pathway for GSSG efflux ${ }^{33}$. Although GSSG represents approximately $1 \%$ of the total glutathione in the cell under basal conditions, a striking increase is found in cells undergoing oxidative stress. GSH depletion has long been considered to play a causal role in oxidative stress-related cellular dysfunction/cell death; however, evidence is emerging that increased cellular GSSG accumulation may be of equal, if not greater, importance in regulating oxidative stress-triggered detrimental effects. Alterations in GSSG generation, recycling, and/or efflux have all been reported to be associated with correspondingly altered cell vulnerability to cell death in response to various cellular stresses. For instance, in mouse embryonic stem cells, targeted disruption of glucose-6-phosphate dehydrogenase, which is the rate-limiting enzyme in the pentose phosphate pathway, the predominant metabolic pathway for the generation of NADPH (a cofactor of GR), renders cells extremely sensitive to $\mathrm{H}_{2} \mathrm{O}_{2}$-induced cell death $^{34}$. Moreover, MRP-1 gene silencing results in cellular GSSG accumulation and cell death ${ }^{33}$. Studies with exogenous GSSG supplementation have documented that GSSG exposure is associated with apoptosis induction involving the p38 mitogen-activated protein kinase pathway $^{35}$. Furthermore, direct GSSG delivery into cells via microinjection induces neural cell death via a 12lipoxygenase pathway ${ }^{36}$. In the present study, disrupted hepatic glutathione homeostasis was observed in mice chronically exposed to a HFD diet, which is characterized by GSH reduction and GSSG elevation. Although the direct cytotoxic effects of high cellular GSSG levels have been documented in a variety of cell types ${ }^{33-36}$, our cell culture studies with hepatocytes revealed that increased GSSG accumulation, despite being non-toxic per se, could sensitize hepatocytes to TNF $\alpha$-induced killing, suggesting that GSSG and TNF $\alpha$ can synergistically induce hepatocyte death and that GSSG-triggered sensitization to TNF $\alpha$ 
hepatotoxicity represents a clinically relevant process that may account for disease progression in NAFLD.

In addition to acting as a master regulator of immune responses, NF- $\mathrm{kB}$ signaling also serves as the switch between life and death in hepatocytes in response to TNF $\alpha$ stimulation. Inhibition of NF- $\mathrm{KB}$ signaling sensitizes a variety of cell types to TNF $\alpha$ killing, including hepatocytes. Mice with a deficiency of key components in the NF- $\mathrm{KB}$ pathway die as a result of massive hepatocyte apoptosis induced by $\mathrm{TNF} \alpha^{37,38}$, supporting the critical role of maintenance of hepatocyte NF- $\mathrm{kB}$ pathway in protecting against TNF $\alpha$ cytotoxicity. In this study, we demonstrated that GSSG accumulation induced by either $\mathrm{H}_{2} \mathrm{O}_{2}$ exposure or GR inhibition suppressed TNF $\alpha$ induced NF- $\kappa B$ activation. Specifically, we found that GSSG elevation suppressed the phosphorylation/activation of IKK- $\beta$, a proximal kinase in the NF- $\mathrm{kB}$ signaling pathway that phosphorylates IKB- $\alpha$, leading to its proteasomal degradation and subsequent NF- $\kappa B$ activation. Consistent with this observation, decreased TNF $\alpha$ stimulated IкB- $\alpha$ phosphorylation was observed in hepatocytes with elevated GSSG levels. These data collectively suggest that the inhibitory effect of GSSG on the NF- $k B$ signaling pathway, via suppression of IKK- $\beta$ activation, is mechanistically implicated in the increased sensitivity of hepatocytes to TNF $\alpha$ killing.

Glutathionylation is a form of $S$-thiolation where protein cysteines form a disulfide bond with the cysteine of glutathione. Akin to several well-established post-translational modification (PTM) processes, e.g., phosphorylation, acetylation, and methylation, $S$-glutathionylation has recently been determined to play an important role in regulating protein function. Although protein $S$-glutathionylation (a process that generates protein-SSG adducts) can be achieved via several different reactions; one well-established biochemical event for the formation of protein-SSG is the reaction of GSSG with protein sulfhydryls. In fact, in cells undergoing lethal oxidative stress, cellular protein-SSG levels show a positive relationship with GSSG levels ${ }^{39}$. Like other PTMs, the effects of $S$-glutathionylation on proteins are diverse and both cell type- and target-specific. However, unlike other PTMs, the involvement of which in NAFLD has been extensively investigated, whether protein $S$-glutathionylation contributes to the pathogenesis of NAFLD remains unclear. To our knowledge, this has been documented to date in only one report showing that patients with NAFLD had increased hepatic protein glutathionylation, which was correlated with steatohepatitis and liver fibrosis ${ }^{40}$. In the current study, we clearly demonstrated that NAFLD induced by long-term HFD consumption was associated with increased hepatic protein-SSG formation. The observation in this study in hepatocytes that protein-SSG formation by either GSSG accumulation or treatment with a direct $S$-glutathionylation induction agent resulted in IKK- $\beta$-SSG formation, leading to its suppression, was supported by a previous study reporting that $S$-glutathionylation was associated with suppressed IKK- $\beta$ activity in epithelial cells ${ }^{41}$. Importantly, our cell culture observations were corroborated by our results obtained in animal studies, suggesting that increased hepatic protein $S$-glutathionylation contributes to NAFLD pathogenesis via suppression of the NF- $\mathrm{KB}$ signaling pathway in hepatocytes.

Although protein-SSG formation occurs by nonenzymatic mechanisms, the de-glutathionylation of proteins is mainly catalyzed by $\mathrm{Grxs}^{32}$. To date, two mammalian Grxs have been characterized, with Grx1 being mostly cytosolic and Grx2 found primarily in mitochondria. Grx1 knockout mice show increased cellular protein $S$-glutathionylation ${ }^{42}$, and Grx2 knockout increases sensitivity to oxidative stress in mouse lens epithelial cells ${ }^{43}$. In the present study, we demonstrated that long-term HFD consumption was associated with decreased protein levels of both Grxs. These data collectively suggest that the observed increase in hepatic protein-SSG formation in HFD-fed animals can result from a combination of both increased $S$-glutathionylation processes and suppressed de-glutathionylation reactions.

The effects of long-term HFD consumption on hepatic NF- $\mathrm{KB}$ activity remain controversial. The discrepancies could derive from the differences in the experimental dietary fat levels, feeding durations, and cell types studied. In the present study, we clearly demonstrated that longterm HFD consumption decreased hepatic NF- $\mathrm{kB}$ activity. This observation is consistent with a previous report demonstrating that long-term HFD consumption impaired liver regeneration in $\mathrm{C} 57 \mathrm{BL} / 6$ mice through suppression of NF- $\mathrm{kB}$ activation ${ }^{44}$. It is noteworthy that long-term HFD consumption may differentially regulate NF- $\mathrm{B}$ activity in hepatocytes (inhibition) and Kupffer cells (activation by lipopolysaccharide). A similar scenario has in fact been reported recently in an alcoholic liver disease model in which long-term alcohol consumption activated NF- $\mathrm{kB}$ in Kupffer cells, whereas NF-кB activation in hepatocytes was inhibited ${ }^{45}$.

In conclusion, our study demonstrates that long-term HFD consumption results in a concomitant increase in hepatic GSSG, protein $S$-glutathionylation, and TNFo levels. Our mechanistic investigations revealed that intracellular GSSG elevation sensitizes hepatocytes to TNF $\alpha$ killing by inducing IKK- $\beta$-SSG formation, leading to suppressed NF- $\mathrm{KB}$ activation. Our results suggest that both increased $S$-glutathionylation processes and suppressed de-glutathionylation reactions contribute to hepatic $S$-glutathionylation in NAFLD. Our data provide important new information concerning potential interactions between GSSG, protein glutathionylation, and 
TNF $\alpha$-induced hepatotoxicity, as well as its critical involvement in the pathogenesis of NAFLD. Collectively, these data support the conclusion that increased cellular GSSG accumulation in hepatocytes plays a critical role in the pathogenesis of NAFLD and may represent a potential therapeutic target for the treatment of NAFLD.

\section{Acknowledgements}

This work was supported by grants from the NIH (NIAAAR01 AA017442, Z.S.), the Natural Science Foundation of China (81470845, Z.S.; 81573132, S.L.; and 81473393, X.D.), the Natural Science Foundation of Heilongjiang Province (LC2015030, S.L.), the China Postdoctoral Science Foundation (2015M570302 and 2016 T90315 to S.L.), and the National Basic Program Research of China (973 program, 2014 CB543001, X.D.).

\section{Author details}

'Department of Kinesiology and Nutrition, University of Illinois at Chicago, Chicago, IL 60612, USA. ${ }^{2}$ College of Life Science, Zhejiang Chinese Medical University, Hangzhou, Zhejiang 310053, P. R. China. ${ }^{3}$ Department of Nutrition and Food Hygiene, Public Health College, Harbin Medical University, Harbin 150086, P. R. China. ${ }^{4}$ Department of Pathology, University of Illinois Medical Center, Chicago, IL 60612, USA

\section{Conflict of interest}

The authors declare that they have no conflict of interest.

\section{Publisher's note}

Springer Nature remains neutral with regard to jurisdictional claims inpublished maps and institutional affiliations.

Received: 28 March 2017 Accepted: 1 November 2017. Published online: 6 April 2018

\section{References}

1. Choudhury, J. \& Sanyal, A. J. Insulin resistance and the pathogenesis of nonalcoholic fatty liver disease. Clin. Liver Dis. 8, 575-594 (2004). ix.

2. Day, C. P. \& James, O. F. Steatohepatitis: a tale of two "hits"? Gastroenterology 114, 842-845 (1998).

3. James, O. F. \& Day, C. P. Non-alcoholic steatohepatitis (NASH): a disease of emerging identity and importance. J. Hepatol. 29, 495-501 (1998).

4. Aragno, M. et al. SREBP-1c in nonalcoholic fatty liver disease induced by Western-type high-fat diet plus fructose in rats. Free Radic. Biol. Med. 47, 1067-1074 (2009).

5. Jou, J., Choi, S. S. \& Diehl, A. M. Mechanisms of disease progression in nonalcoholic fatty liver disease. Semin. Liver Dis. 28, 370-379 (2008).

6. Knebel, B. et al. Liver-specific expression of transcriptionally active SREBP-1C is associated with fatty liver and increased visceral fat mass. PLOS ONE 7, e31812 (2012).

7. Akazawa, Y. et al. Palmitoleate attenuates palmitate-induced Bim and PUMA up-regulation and hepatocyte lipoapoptosis. J. Hepatol. 52, 586-593 (2010).

8. Donnelly, K. L. et al. Sources of fatty acids stored in liver and secreted via lipoproteins in patients with nonalcoholic fatty liver disease. J. Clin. Invest. 115 1343-1351 (2005).

9. Videla, L. A. et al. Oxidative stress-related parameters in the liver of nonalcoholic fatty liver disease patients. Clin. Sci. (Lond.). 106, 261-268 (2004).

10. Erhardt, A. et al. Plasma levels of vitamin $\mathrm{E}$ and carotenoids are decreased in patients with nonalcoholic Steatohepatitis (NASH). Eur. J. Med. Res. 16, 76-78 (2011).

11. Liu, S. et al. Plasma reactive carbonyl species levels and risk of non-alcoholic fatty liver disease. J. Gastroenterol. Hepatol. 26, 1010-1015 (2011).

12. Matsuzawa, N. et al. Lipid-induced oxidative stress causes steatohepatitis in mice fed an atherogenic diet. Hepatology 46, 1392-1403 (2007).

13. Koek, G. H., Liedorp, P. R. \& Bast, A. The role of oxidative stress in non-alcoholic steatohepatitis. Clin. Chim. Acta 412, 1297-1305 (2011).
14. Rolo, A. P., Teodoro, J. S. \& Palmeira, C. M. Role of oxidative stress in the pathogenesis of nonalcoholic steatohepatitis. Free Radic. Biol. Med. 52, 59-69 (2012).

15. Lee, Y. M. et al. A randomized controlled pilot study of pentoxifylline in patients with non-alcoholic steatohepatitis (NASH). Hepatol. Int. 2, 196-201 (2008).

16. Khoshbaten, M. et al. N-acetylcysteine improves liver function in patients with non-alcoholic fatty liver disease. Hepat. Mon. 10, 12-16 (2010).

17. Malaguarnera, M. et al. L-carnitine supplementation to diet: a new tool in treatment of nonalcoholic steatohepatitis - a randomized and controlled clinical trial. Am. J. Gastroenterol. 105, 1338-1345 (2010).

18. Van Wagner, L. B. et al. Pentoxifylline for the treatment of non-alcoholic steatohepatitis: a randomized controlled trial. Ann. Hepatol. 10, 277-286 (2011).

19. Harrison, S. A., Torgerson, S., Hayashi, P., Ward, J. \& Schenker, S. Vitamin E and vitamin $C$ treatment improves fibrosis in patients with nonalcoholic steatohepatitis. Am. J. Gastroenterol. 98, 2485-2490 (2003).

20. Sanyal, A. J. et al. Pioglitazone, vitamin E, or placebo for nonalcoholic steatohepatitis. N. Engl. J. Med. 362, 1675-1685 (2010).

21. Crespo, J. et al. Gene expression of tumor necrosis factor alpha and TNFreceptors, p55 and p75, in nonalcoholic steatohepatitis patients. Hepatology 34, 1158-1163 (2001).

22. Tokushige, $\mathrm{K}$ et al. Influence of TNF gene polymorphisms in Japanese patients with NASH and simple steatosis. J. Hepatol. 46, 1104-1110 (2007).

23. Li, Z. et al. Probiotics and antibodies to TNF inhibit inflammatory activity and improve nonalcoholic fatty liver disease. Hepatology $\mathbf{3 7}$, 343-350 (2003).

24. Lin, H. Z. et al. Metformin reverses fatty liver disease in obese, leptin-deficient mice. Nat. Med. 6, 998-1003 (2000).

25. $\mathrm{Xu}, \mathrm{A}$. et al. The fat-derived hormone adiponectin alleviates alcoholic and nonalcoholic fatty liver diseases in mice. J. Clin. Invest. 112, 91-100 (2003).

26. Feldstein, A. E. et al. Free fatty acids promote hepatic lipotoxicity by stimulating TNF-alpha expression via a lysosomal pathway. Hepatology 40, 185-194 (2004).

27. Tomita, K. et al. Tumour necrosis factor alpha signalling through activation of Kupffer cells plays an essential role in liver fibrosis of non-alcoholic steatohepatitis in mice. Gut 55, 415-424 (2006).

28. Brenner, C., Galluzzi, L., Kepp, O. \& Kroemer, G. Decoding cell death signals in liver inflammation. J. Hepatol. 59, 583-594 (2013).

29. Wu, G., Fang, Y. Z., Yang, S., Lupton, J. R. \& Turner, N. D. Glutathione metabolism and its implications for health. J. Nutr. 134, 489-492 (2004).

30. Kleiner, D. E. et al. Design and validation of a histological scoring system for nonalcoholic fatty liver disease. Hepatology 41, 1313-1321 (2005).

31. Allen, E. M. \& Mieyal, J. J. Protein-thiol oxidation and cell death: regulatory role of glutaredoxins. Antioxid. Redox Signal. 17, 1748-1763 (2012).

32. Li, S., Zhou, H., Huang, G. \& Liu, N. Inhibition of HBV infection by bovine lactoferrin and iron-, zinc-saturated lactoferrin. Med. Microbiol. Immunol. 198, 19-25 (2009).

33. Gordillo, G. M. et al. Multidrug resistance-associated protein-1 (MRP-1)dependent glutathione disulfide (GSSG) efflux as a critical survival factor for oxidant-enriched tumorigenic endothelial cells. J. Biol. Chem. 291, 10089-10103 (2016).

34. Fico, A. et al. Glucose-6-phosphate dehydrogenase plays a crucial role in protection from redox-stress-induced apoptosis. Cell Death Differ. 11, 823-831 (2004).

35. Filomeni, G., Rotilio, G. \& Ciriolo, M. R. Glutathione disulfide induces apoptosis in U937 cells by a redox-mediated p38 MAP kinase pathway. FASEB J. 17, 64-66 (2003).

36. Park, H. A. et al. Glutathione disulfide induces neural cell death via a 12lipoxygenase pathway. Cell Death Differ. 16, 1167-1179 (2009).

37. Tanaka, M. et al. Embryonic lethality, liver degeneration, and impaired NFkappa B activation in IKK-beta-deficient mice. Immunity 10, 421-429 (1999).

38. Chaisson, M. L., Brooling, J. T., Ladiges, W., Tsai, S. \& Fausto, N. Hepatocytespecific inhibition of NF-kappaB leads to apoptosis after TNF treatment, but not after partial hepatectomy. J. Clin. Invest. 110, 193-202 (2002).

39. Franco, R. \& Cidlowski, J. A. Apoptosis and glutathione: beyond an antioxidant Cell Death Differ. 16, 1303-1314 (2009). 
40. Piemonte, F. et al. Protein glutathionylation increases in the liver of patients with non-alcoholic fatty liver disease. J. Gastroenterol. Hepatol. 23, e457-e464 (2008).

41. Reynaert, N. L. et al. Dynamic redox control of NF-kappaB through glutaredoxin-regulated S-glutathionylation of inhibitory kappaB kinase beta. Proc. Natl Acad. Sci. USA 103, 13086-13091 (2006).

42. Ho, Y. S. et al. Targeted disruption of the glutaredoxin 1 gene does not sensitize adult mice to tissue injury induced by ischemia/ reperfusion and hyperoxia. Free Radic. Biol. Med. 43, 1299-1312 (2007).
43. Wu, H., Lin, L., Giblin, F., Ho, Y. S. \& Lou, M. F. Glutaredoxin 2 knockout increases sensitivity to oxidative stress in mouse lens epithelial cells. Free Radic. Biol. Med. 51, 2108-2117 (2011).

44. DeAngelis, R. A., Markiewski, M. M., Taub, R. \& Lambris, J. D. A high-fat diet impairs liver regeneration in C57BL/6 mice through overexpression of the NF-kappaB inhibitor, IkappaBalpha. Hepatology 42, 1148-1157 (2005).

45. Mandrekar, P., Ambade, A., Lim, A., Szabo, G. \& Catalano, D. An essential role for monocyte chemoattractant protein-1 in alcoholic liver injury: regulation of proinflammatory cytokines and hepatic steatosis in mice. Hepatology 54, 2185-2197 (2011) 